\title{
REPRODUCTIVE CYCLE OF FEMALE COMMON INDIAN ROCK LIZARD, PSAMMOPHILUS BLANFORDANUS: SEASONAL OVARY AND OVIDUCT HISTOLOGY
}

\author{
Deepak Kumar Singh ${ }^{1}$, Nakulananda Mohanty ${ }^{2 *}$ and Nirakar Jena ${ }^{3}$ \\ Department of Zoology, Govt. (Auto) College, Rourkela-769004, Odisha ${ }^{1}$ \\ P.G. Department of Zoology, North Orissa University, Baripada-757003, Odisha ${ }^{2}$ \\ P.G. Department of Life Sciences, Govt. (Auto) College, Phulbani-762001, Odisha ${ }^{3}$ \\ Corresponding author: nakulanandamohanty@gmail.com
}

\begin{abstract}
The lizard Psammophilus (Reptilia: Diapsida: Agamidae) is commonly called as rock lizard. It has only been reported that female P. blanfordanus is a seasonal breeder otherwise research on its reproduction is limited. Therefore, to investigate the relationship between environmental and reproductive behaviour, studies on gonadosomatic index (GSI), histology and histometry of ovary and oviduct were undertaken. The GSI, relative weight of ovaries (ROW) and oviducts (ROiW) are highest during the breeding season. The ROW and ROiW are positively correlated with temperature, rainfall and relative humidity $(\mathrm{RH})$. The histology and histometry of ovary and oviducts show that the breeding season in this animal is from April to June/July and sometimes extends to early August. During this period the diameter of oocyte, oviduct and oviduct glandular layer is increased. The thickness of oviduct glandular is also increased but thickness of oviduct muscle layer is decreased. The reproductive cycle of this animal is associate type. The study will be helpful in understanding its evolutionary adaptability to different seasons.
\end{abstract}

KEYWORDS: Reptilia, Diapsida, Agamidae, female P. blanfordanus, ovary, oviduct, histology

\section{INTRODUCTION}

Reproduction is a rhythmic phenomenon in most of the vertebrates. In the case of seasonal breeders, it is confined to short period(s) of the year called as the "breeding season" and they are sexually inactive during the rest part of the year ${ }^{1}$. For this, each sex must be reproductively ready when the opposite sex is ready. However, this does not happen all the time. Sometimes the gametes of male and female mature at different time of the year. Due to these differences in reproductive cycles among sexes, the reproductive cycle has been classified under three categories: 1) Continuous reproductive cycle - Both mating and gametogenesis occur almost all round the year; 2) Dissociated reproductive cycle- Mating period is brief and sperm storage takes place inside the female until fertilisation takes place; and 3) Associated reproductive cycle - The gonadal and hormonal events are closely related or coincide in both the sexes, so that spermatogenesis and oogenesis take place at the same time $e^{2,3,4,5}$.

The effect of environmental factors on seasonal rhythms is operational at two levels, the ultimate and the proximate ${ }^{6}$. The main ultimate factors include dietary and climatic factors (food availability, rainfall and temperature in particular), predator pressure and competition between species. On the other hand, the proximate factors 
provide immediate cueing for the control of annual rhythms by regulating physiological process. The relationship between reproductive cycles and climate suggests that reproduction in lizards is affected by environmental variables such as ambient temperature $^{7,8}$, precipitation $^{9,10}$ photoperiod $^{11}$ and food ${ }^{12,13}$.

Though works on reproductive cycle of the most of the Indian lizards have been summarised by Fitch ${ }^{14}$, still it is scanty. Later works on common agamid on these parameters of female include Calotes nemericola $^{15}$, C. versicolor ${ }^{16,17,18,19,20}$, Psammophilus dorsalis ${ }^{21}$, Sitana ponticeriana $^{15,22}$, geckos $^{17,23,24,25}$ and Varanus $\mathrm{sp.}^{26}$.

The family Agamidae in Odisha (India) is represented by three genera (Calotes, Psammophilus and Sitana $)^{27}$. Lizards belong to the genus Psammophilus are usually called as the common Indian rock lizards. Under this genus two species have been described, i.e., $P$. dorsalis and $P$. blanfordanus $^{28}$ which are tropical lizards. The extensive literature based on this genus is dominated by research on reproduction

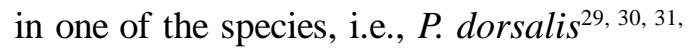
32. Works in this regard on the present species, P.blanfordanus is very small. The works of Pradhan ${ }^{33}$ is confined to the morphology, and earlier classical studies on reproduction on this animal have only mentioned about its breeding season ${ }^{28,34}$. They have informed that the reproductive season of this animal is from April to June.

Therefore, attempts have been made to draw the information together into a coherent and complete picture of relationship between environmental factors and reproductive behaviour of female $P$. blanfordanus $^{35}$ (Reptilia: Diapsida: Agamidae), the common Indian rock lizard or Blanfordanus rock lizard. This animal model is selected as because it is abundant, docile, and relatively large. Varied parameters like gonadosomatic index (GSI), histology and histometry of ovary and oviduct have been used in understanding the pattern of their reproductive cycle and also to know its reproductive characteristics in breeding and non-breeding (quiescence and recrudescence) seasons. Unlike mammals, the size of the oocyte in reptile is important, as it accumulates a large amount of yolk for the developing embryo. Therefore, its diameter will reflect the state of vitellogenesis, thereby, reproductive status of the animal. In support of reproductive status, the thickness of oviduct muscle and glandular layers were also studied. Further, the weight of the sex organs was correlated with the temperature, rainfall and relative humidity $(\mathrm{RH})$ to know whether environmental factors have any influence or not on its reproductive behaviour. The study will give an idea about its seasonal adaptability, and will add knowledge on studying comparative phylogeny of vertebrates.

\section{MATERIALS AND METHODS}

Animal. The animals were collected randomly from the open field during the 
early morning hours as they are active in that period in and around Baripada, Mayurbhanj, Odisha $\left(20^{0} 16^{1}\right.$ and $22^{0} 34^{1} \mathrm{~N}$; $85^{\circ} 40^{1}$ and $87^{\circ} 11^{1} \mathrm{E}$ ). After capture they were brought to the laboratory. The animals were tentatively sexed by examining relative head width, overall body size and shape. However, sex was confirmed by visual examination of the cloacal opening for the presence or absence of hemipenis. Sexually mature females were considered for study. The sexual maturity was ascertained by the method of Pradhan ${ }^{33}$. Besides, those females containing yolky follicles in the ovary or eggs in the oviduct were also judged as reproductively active ones. In the laboratory, they were acclimatised at least for 15 days by keeping them in clean cages fed with insects and sometimes live earthworms and water was provided ad libitum. A minimum of 5 to 9 mature females were collected for each month.

Morphometry. In the laboratory, each lizard was weighed approximately to $1.0 \mathrm{~g}$ (nearest $0.01 \mathrm{~g}$ ) with the Pesola Spring Scale, and measurement of snout to vent length (SVL) and tail length (TL) to $1.0 \mathrm{~mm}$ were done by measuring tape and nearest to $0.1 \mathrm{~mm}$ with Mitutoyo digital calliper. The ovary and oviduct were dissected out after sacrificing the animal by decapitation, cleaned from adhering fats and tissues and weighed to nearest $0.001 \mathrm{~g}$ by Schimazdu monopan balance. To reduce variability due to body weight, the organ weights have been expressed basing upon somatic indices (organ weight/ body weight $x$ 100) (GSI).
The relative weight of the organs (organ weight/100g body weight) was also calculated. It was observed that the size and weight of both the ovaries were same, and when required data were pooled together from two ovaries.

Histology and Histometry. The following have been worked out to know the reproductive state of the animal. The status of the follicles was recorded on the presence or absence of yolk (or transparent follicle) and their diameter was measured. The diameter of the oocyte was also recorded and the condition of the oviduct (contracted or distended) was also marked. The granulosa cell height (thickness) of largest follicle was calculated by deducting oocyte diameter from follicle diameter. The thickness of oviductal muscle and grandular layers was also recorded. The ovary (after observing yolky follicles) and oviduct were fixed in Bouin's fluid for above histological and histometric studies. The number of developing follicles, yolky follicles, atretic follicles and corpora lutea was counted. To consider the follicle as atretic, the criteria of Guraya ${ }^{36}$ and Wang et al. ${ }^{37}$ were followed. The early sign was the disintegration of follicles with reduction in size. The thecal layer was less vascularised, thinner and fibrous. In the late stages, the follicles shrunk, wrinkled and granulosa layers were no longer seen. These were replaced by large irregular cells which diffused into ooplasm and started phagocitising.

Meteorology. The meteorological data in respect of rainfall $(\mathrm{mm})$, temperature $\left({ }^{\circ} \mathrm{C}\right)$ 
and relative humidity (RH) (\%) were collected from State Meteorological Department stationed at Baripada for the study periods and correlated with weight of ovary and oviduct. Here we considered MidMarch to Mid-June, July to Mid-September and Mid-October to February as Summer, Rainy and Winter seasons, respectively.

Statistical Analysis. The relative weight of ovary and oviduct was correlated with meteorological data (temperature, rainfall and humidity) using linear regression and coefficient of correlation analyses were performed taking meteorological data as independent variable $^{38}$.

\section{RESULTS AND DISCUSSION}

\section{Morphometry}

The data on body weight revealed that there was a seasonal variation in the body weight (Table 1). Between September and February/March, the body weight was low and the body weight was minimal in October (34.56 g). Thereafter, the body weight increased gradually and was maximum (44.47g in July) from late June to August (Table 1). The GSI was lowest during December (0.228) and highest during June (6.820) and a sub-peak in July (4.578) (Table 1).Further, the GSI was also high from April - August/September and low during October to March (Table 1). The snout to vent length (SVL) ranged from 8.93 $\mathrm{cm}$ to $9.67 \mathrm{~cm}($ mean $=9.47 \mathrm{~cm})$ and the tail length (TL) from $18.27 \mathrm{~cm}$ to $19.63 \mathrm{~cm}$ $($ mean $=19.24 \mathrm{~cm})($ Table 1$)$.
The relative weight of the ovaries (ROW) showed cyclical changes, being higher during the period from April to August reaching peak during July $(4,903.82$ $\mathrm{mg}$ ) and sub-peaks in June $(4,774.99 \mathrm{mg})$ and August (4,089.79 mg) (Table 1). It was low during the period from October to March (Table 1). The lowest was observed in December (130.07 mg) which is 38 times less than that of the value of July (Table 1).

The change in relative weight of the oviducts (ROiW) with season was similar to that of the ROW. It was lowest in January (396.56 mg) and highest in August $(22,867.75 \mathrm{mg})$. The two other sub-peaks were in July $(11,304.16 \mathrm{mg})$ and September $(15,191.60 \mathrm{mg})$.

\section{Histology and Histometry}

Ovary. It was observed that the ovaries contained mature and immature ova throughout the year. Oogonia were found in germinal epithelium, but they were abundant in ovaries from March. Once the follicle was formed and developing, these were pushed out of the germinal bed. The germinal bed was present at the dorsal surface of the ovary as a single band in this animal. These developing follicles were generally seen throughout the year. Its number was more in March (86.67\%) and slightly decreased from April to August (Tables 2 and 3 ). The size of these developing follicles ranged from $0.40 \mathrm{~mm}$ $(400 \mu \mathrm{m})$ to $1.90 \mathrm{~mm}(1,900 \mu \mathrm{m})$. Out of these follicles 8-20 follicles were under active growth and may be called as previtellogenic follicles (Table 3). Yolky 
Table 1. Seasonal variation in the body weight, gonadosomatic index (GSI), snout to vent length (SVL), tail length (TL), relative ovarian weight (ROW), relative oviductal weight (ROiW) of female P. blanfordanus. Unit of measurement and number of animals are given in parentheses. Data are mean \pm standard deviation

\begin{tabular}{|l|c|c|c|c|c|c|c|}
\hline Month & $\begin{array}{c}\text { Number of } \\
\text { animals } \\
(\mathrm{n})\end{array}$ & $\begin{array}{c}\text { Body weight } \\
(\mathrm{g})\end{array}$ & GSI & $\begin{array}{c}\text { SVL }(\mathrm{cm}) \\
(\mathrm{n}=120)\end{array}$ & $\begin{array}{c}\text { TL }(\mathrm{cm}) \\
(\mathrm{n}=120)\end{array}$ & $\begin{array}{c}\text { ROW(mg/100 g } \\
\text { body weight })\end{array}$ & $\begin{array}{c}\text { ROiW(mg/100 g } \\
\text { body weight })\end{array}$ \\
\hline January & 6 & $35.74 \pm 2.87$ & 0.295 & $8.93 \pm 0.79$ & $18.27 \pm 0.96$ & $249.64 \pm 17.79$ & $396.56 \pm 31.82$ \\
\hline February & 5 & $34.97 \pm 2.05$ & 0.282 & $9.50 \pm 0.61$ & $18.73 \pm 0.79$ & $269.76 \pm 19.45$ & $617.60 \pm 51.76$ \\
\hline March & 6 & $35.93 \pm 3.05$ & 0.737 & $9.23 \pm 0.35$ & $19.06 \pm 0.51$ & $363.83 \pm 44.04$ & $1041.05 \pm 87.14$ \\
\hline April & 5 & $37.31 \pm 2.75$ & 3.486 & $9.59 \pm 0.66$ & $19.46 \pm 0.51$ & $1734.49 \pm 238.16$ & $5945.18 \pm 765.59$ \\
\hline May & 7 & $37.43 \pm 3.56$ & 3.789 & $9.13 \pm 0.40$ & $19.23 \pm 0.51$ & $2836.59 \pm 1410.46$ & $3679.49 \pm 360.41$ \\
\hline June & 7 & $36.64 \pm 2.36$ & 6.820 & $9.20 \pm 0.60$ & $19.26 \pm 0.85$ & $4774.99 \pm 1143.42$ & $7403.45 \pm 781.16$ \\
\hline July & 5 & $44.47 \pm 2.06$ & 4.578 & $9.64 \pm 0.87$ & $19.63 \pm 0.35$ & $4903.82 \pm 2669.98$ & $1304.16 \pm 1818.35$ \\
\hline August & 6 & $42.13 \pm 1.96$ & 3.100 & $9.43 \pm 0.59$ & $19.34 \pm 0.86$ & $4089.79 \pm 1786.99$ & $22867.75 \pm 948.79$ \\
\hline September & 7 & $35.60 \pm 2.13$ & 2.928 & $9.40 \pm 0.82$ & $19.60 \pm 0.52$ & $1591.41 \pm 699.70$ & $15191.60 \pm 2355.71$ \\
\hline October & 8 & $34.56 \pm 2.35$ & 0.534 & $9.64 \pm 0.38$ & $19.29 \pm 0.37$ & $316.85 \pm 21.12$ & $3647.08 \pm 616.85$ \\
\hline November & 7 & $35.31 \pm 2.39$ & 0.308 & $9.53 \pm 0.20$ & $19.50 \pm 0.28$ & $186.15 \pm 11.25$ & $490.40 \pm 81.83$ \\
\hline December & 7 & $36.60 \pm 2.45$ & 0.228 & $9.67 \pm 0.14$ & $19.54 \pm 0.29$ & $130.07 \pm 9.18$ & $429.95 \pm 52.56$ \\
\hline
\end{tabular}

follicles and luteal phase were uncommon during this period (Table 2). However, few corpora lutea of the previous cycle in their final stage of degeneration were still seen. These were disappeared completely in April with the onset of vitellogenesis. The vitellogenesis continued till July and these yolk ladden follicles are called as yolky follicles. In both the ovaries the number of yolky follicles (around $7.0 \mathrm{~mm}$ to $9.0 \mathrm{~mm}$ in diameter) ranged from 12 to 18 (Table 2). Since they are ready to be ovulated, therefore, such follicles be called as the preovulatory follicles (Table 3). These preovulatory follicles (ranged from 7.0 to $9.0 \mathrm{~mm}$ in size) consist of a single large yolk mass with inconspicuous vitelline membrane and zona radiata, with thin and intensely vascularised theca layer.

The process of ovulation mainly began towards the end of March (as indicated by the presence of corpora lutea) and continued till September early October (Table 2). With the ovulation, to each oviductal egg there was an equal number of corpus luteum in corresponding ovary. After ovulation a few large yolky follicles were still seen in the ovaries with already a set of eggs in the 
Table 2. Seasonal variation in the number of ovarian components like developing follicles, yolky follicles, atretic follicles and corpora lutea of female P. blanfordanus. Percentage of ovarian components and its number are given in parentheses

\begin{tabular}{|l|c|c|c|c|c|}
\hline Month & $\begin{array}{c}\text { Number of } \\
\text { ovarian } \\
\text { component }(\mathrm{n})\end{array}$ & $\begin{array}{c}\text { Developing } \\
\text { follicles }\end{array}$ & Yolky follicles & Atretic follicles & Corpora lutea \\
\hline January & 38 & $25(65.79 \%)$ & - & $13(34.21 \%)$ & - \\
\hline February & 39 & $29(74.36 \%)$ & - & $10(25.64 \%)$ & - \\
\hline March & 45 & $39(86.67 \%)$ & $2(4.44 \%)$ & $3(6.67 \%)$ & $1(2.22 \%)$ \\
\hline April & 52 & $35(67.31 \%)$ & $15(28.85 \%)$ & $1(1.92 \%)$ & $1(1.92 \%)$ \\
\hline May & 61 & $40(65.57 \%)$ & $17(27.87 \%)$ & $1(1.64 \%)$ & $3(4.92 \%)$ \\
\hline June & 63 & $43(68.25 \%)$ & $14(22.22 \%)$ & - & $6(9.52 \%)$ \\
\hline July & 62 & $35(56.45 \%)$ & $17(27.42 \%)$ & - & $10(16.13 \%)$ \\
\hline August & 58 & $39(67.24 \%)$ & $7(12.07 \%)$ & - & $12(20.69 \%)$ \\
\hline September & 56 & $34(60.71 \%)$ & $4(7.14 \%)$ & $4(7.14 \%)$ & $14(25.00 \%)$ \\
\hline October & 52 & $32(61.54 \%)$ & $1(1.92 \%)$ & $13(25.00 \%)$ & $6(11.54 \%)$ \\
\hline November & 41 & $21(51.22 \%)$ & - & $17(41.46 \%)$ & $3(7.32 \%)$ \\
\hline December & 34 & $21(61.76 \%)$ & - & $12(35.29 \%)$ & $1(2.94 \%)$ \\
\hline
\end{tabular}

oviduct. More atretic follicles were generally seen from October to February and were seen less in number from March to May and was almost absent from June to August (Table 2). These atretic follicles lacked both vitelline and zona pellucida layers and number of phagocytic granulosa cells proliferate which were surrounded by hypertrophied theca. Atresia was also seen in the vitellogenic follicles which were not ovulated. The size of the atretic follicles varied from $0.2 \mathrm{~mm}$ to $0.8 \mathrm{~mm}$.

The oocyte diameter $(3,865.65 \pm$ 379.95 ìm) was highest in July (Table 4).
Therefore, it gradually decreased after that and reached lowest $(565.96 \pm 69.31$ ìm $)$ value in December (Table 4). It was usually higher from March to September (Table 4). The height of the granulosa cell layers ranged from 48-58 ìm from the month of October to February and between 23-36 ìm from the month of March to September (Table 4).

Oviduct. The oviduct is a paired elongated tubular structure present on either side of the ovary and directly empties into cloaca. The changes in morphological and histological structures of oviduct with 
Table 3. Seasonal variation in the number of ovarian follicles of different sizes $(\mu \mathrm{m})$ in female P.blanfordanus (Data are mean of 4 animals)

\begin{tabular}{|l|c|c|c|c|c|c|c|c|c|c|c|c|}
\hline Month & $\begin{array}{c}\text { Below } \\
400 \\
\mu \mathrm{m}\end{array}$ & $\begin{array}{c}400- \\
800 \\
\mu \mathrm{m}\end{array}$ & $\begin{array}{c}800- \\
1200 \\
\mu \mathrm{m}\end{array}$ & $\begin{array}{c}1200- \\
1600 \\
\mu \mathrm{m}\end{array}$ & $\begin{array}{c}1600- \\
2000 \\
\mu \mathrm{m}\end{array}$ & $\begin{array}{c}2000- \\
2400 \\
\mu \mathrm{m}\end{array}$ & $\begin{array}{c}2400- \\
2800 \\
\mu \mathrm{m}\end{array}$ & $\begin{array}{c}2800- \\
3200 \\
\mu \mathrm{m}\end{array}$ & $\begin{array}{c}3200- \\
3600 \\
\mu \mathrm{m}\end{array}$ & $\begin{array}{c}3600- \\
4000 \\
\mu \mathrm{m}\end{array}$ & $\begin{array}{c}4000- \\
4400 \\
\mu \mathrm{m}\end{array}$ & $\begin{array}{c}4400 \\
\text { and } \\
\text { above }\end{array}$ \\
\hline January & 12 & 19 & 8 & - & - & - & - & - & - & - & - & - \\
\hline February & 8 & 15 & 11 & 1 & - & - & - & - & - & - & - & - \\
\hline March & 5 & 10 & 10 & 2 & - & 2 & 3 & 9 & 5 & - & 7 & 20 \\
\hline April & 4 & 12 & 19 & 5 & - & - & - & - & - & 5 & 6 & 8 \\
\hline May & 4 & 15 & 17 & 6 & - & - & - & 4 & 4 & 11 & - & 21 \\
\hline June & 3 & 14 & 15 & 5 & 5 & 10 & 5 & 10 & 10 & - & - & 28 \\
\hline July & 2 & 9 & 14 & 4 & 3 & - & - & - & - & 5 & 15 & 32 \\
\hline August & 3 & 10 & 20 & 18 & 7 & - & - & - & - & - & - & 15 \\
\hline September & 5 & 8 & 8 & 9 & 1 & - & - & - & - & - & - & 4 \\
\hline October & 7 & 7 & 15 & - & - & - & - & - & - & - & - & 1 \\
\hline November & 7 & 10 & 12 & - & - & - & - & - & - & - & - & - \\
\hline December & 8 & 8 & 14 & - & - & - & - & - & - & - & - & - \\
\hline
\end{tabular}

$* \mathrm{FD}=$ Follicular Diameter.

NB - Yolk was observed in follicles measuring $2000 \mu \mathrm{m}$ and above in diameter.

season closely followed the ovarian cycle. During the period from late March to early September (gestation) the oviduct (uterus) contained fertilised eggs which were arranged in rows, like beads, whereas, during other parts of the year (non-breeding season) they remained highly convoluted. Its diameter was lowest in December $(112.09 \pm 1.80 \mathrm{im})$ (Table 5). The increase in diameter was well marked in April (214.62 \pm 8.45 ìm) and was highest in August (295.25 \pm 5.69 ìm) (Table 5).

The thickness of the oviduct muscle layer showed reverse trend with that of oviduct diameter (Table 5) and ROiW (Table 1). The thickness of oviductal muscle layer was usually least in July $(7.97 \pm 0.63 \mu \mathrm{m})$ and also in August $(6.73 \pm 0.56 \mathrm{ìm})$ (Table 5). On the other hand, the thickness was highest in December (30.52 ìm) and in January it was 27.32 ìm (Table 5). The data on the thickness of oviduct glandular layer was opposite to that of its muscle layer (Table 5). It showed higher value from the month of March to October and lower value from November to February (Table 5). The 
Table 4. Seasonal variations in the oocyte diameter and follicular granulosa height of female P.blanfordanus. Unit of measurement are given in parentheses and data are mean \pm standard deviation $(\mathrm{n}=68)$

\begin{tabular}{|l|c|c|}
\hline Month & Oocyte diameter $(\mu \mathrm{m})$ & Follicular granulosaheight $(\mu \mathrm{m})$ \\
\hline January & $603.94 \pm 50.79$ & $55.86 \pm 1.42$ \\
\hline February & $659.12 \pm 34.65$ & $54.59 \pm 2.47$ \\
\hline March & $2208.02 \pm 212.63$ & $30.59 \pm 1.35$ \\
\hline April & $2434.64 \pm 205.21$ & $31.92 \pm 1.60$ \\
\hline May & $2571.54 \pm 287.92$ & $28.62 \pm 1.29$ \\
\hline June & $2194.85 \pm 257.21$ & $27.17 \pm 3.36$ \\
\hline July & $3865.65 \pm 379.95$ & $30.80 \pm 1.17$ \\
\hline August & $2424.30 \pm 210.27$ & $29.40 \pm 1.29$ \\
\hline September & $2191.98 \pm 198.35$ & $33.68 \pm 1.99$ \\
\hline October & $763.85 \pm 40.74$ & $51.80 \pm 2.13$ \\
\hline November & $656.85 \pm 40.09$ & $55.68 \pm 1.94$ \\
\hline December & $565.96 \pm 69.31$ & $54.64 \pm 1.62$ \\
\hline
\end{tabular}

thickness of glandular layer in August was $58.93 \pm 2.29$ ìm and in July it was $54.12 \pm$ 1.99 ìm (Table 5).

Clutch size. The clutch size of this animal was 7-9 as observed by the presence of ovulated eggs in its oviducts. This species exhibited another clutch of eggs as evidenced by the presence of second set of vitellogenic follicles (Table 2) along with a set of oviductal eggs. The fertilised eggs were retained 35 to 45 days in the oviducts.

\section{Meteorology}

The coefficient of correlation and regression analyses between temperature $(\mathrm{P}$ $<0.001)$ and rainfall $(\mathrm{P}<0.02)$ with ROW showed a significant and positive correlation
(Fig. 1A, B). The RH though positively correlated it was not significant (Fig. 1C). On the other hand, ROiW had a significant positive relationship with temperature $(\mathrm{P}<$ $0.001)$, rainfall $(\mathrm{P}<0.02)$ and $\mathrm{RH}(\mathrm{P}<$ 0.01) (Fig. 2A, B, C), respectively.

Reptiles, the most primitive amniote vertebrates which successfully colonised the land in the course of vertebrate evolution are admirably well adopted for terrestrial mode of life. The major adaptive features are seen in their reproductive systems and the advent of internal fertilisation, and cleidoic eggs. They have suitably developed accessory reproductive organs for storage and transport. This liberated them from 
Table 5. Seasonal variation in the oviduct diameter, and thickness of its muscular and glandular layers of female P. blanfordanus. Unit of measurement is given in parentheses and data are mean \pm standard deviation $(n=76)$

\begin{tabular}{|l|c|c|c|}
\hline Month & $\begin{array}{c}\text { Diameter of } \\
\text { oviduct }(\mu \mathrm{m})\end{array}$ & $\begin{array}{c}\text { Thickness of oviduct } \\
\text { muscular layer }(\mu \mathrm{m})\end{array}$ & $\begin{array}{c}\text { Thickness of oviduct } \\
\text { glandular layer }(\mu \mathrm{m})\end{array}$ \\
\hline January & $117.75 \pm 1.76$ & $27.32 \pm 0.84$ & $10.48 \pm 0.92$ \\
\hline February & $152.96 \pm 6.78$ & $25.87 \pm 1.56$ & $18.93 \pm 0.73$ \\
\hline March & $170.53 \pm 9.53$ & $18.51 \pm 2.30$ & $36.83 \pm 1.03$ \\
\hline April & $214.62 \pm 8.45$ & $17.31 \pm 3.03$ & $48.53 \pm 2.26$ \\
\hline May & $179.29 \pm 12.02$ & $11.17 \pm 1.05$ & $48.42 \pm 3.24$ \\
\hline June & $212.79 \pm 3.71$ & $10.45 \pm 0.71$ & $50.97 \pm 0.70$ \\
\hline July & $253.84 \pm 4.46$ & $7.97 \pm 0.63$ & $54.12 \pm 1.99$ \\
\hline August & $295.25 \pm 5.69$ & $6.73 \pm 0.56$ & $58.93 \pm 2.29$ \\
\hline September & $233.64 \pm 10.15$ & $14.94 \pm 4.63$ & $47.20 \pm 2.21$ \\
\hline October & $181.94 \pm 2.24$ & $21.00 \pm 2.09$ & $39.78 \pm 1.44$ \\
\hline November & $120.99 \pm 3.23$ & $26.59 \pm 1.91$ & $24.16 \pm 0.55$ \\
\hline December & $112.09 \pm 1.80$ & $30.52 \pm 2.15$ & $16.98 \pm 0.67$ \\
\hline
\end{tabular}

dependence on water for reproduction. This is an adaptive advantage seen in reptiles when compared to amphibians ${ }^{39}$.

The pattern of reproduction and extend of reproductive seasonality differ in the female lizards because of involvement of additional mechanisms and events when compared to male. As discussed earlier, three types of reproductive cycle have been recognised among reptiles ${ }^{2}$. Reproductive patterns of both temperate and tropical zone lizards have been reviewed ${ }^{40}$. Annual reproductive cycle is dependent on a series of changing environmental cues, where a period of hibernation followed by warm climate permits development of follicles, vitellogenesis, ovulation and pregnancy ${ }^{41}$. The reproductive cycle of female $P$. blanfordanus can be distinguishable into five phases based on the complex ovarian events on the basis of the evidences from histology and histometry in different months as opposed to only three phases in male (pre-breeding, breeding and post-breeding). These five phases include i) recrudescence (pre-breeding) (February to March), ii) vitellogenesis, iii) ovulation, iv) pregnancy (followed by oviposition) (breeding) (June to August/ September), and v) regression (post-breeding or quiescence) (September/ 


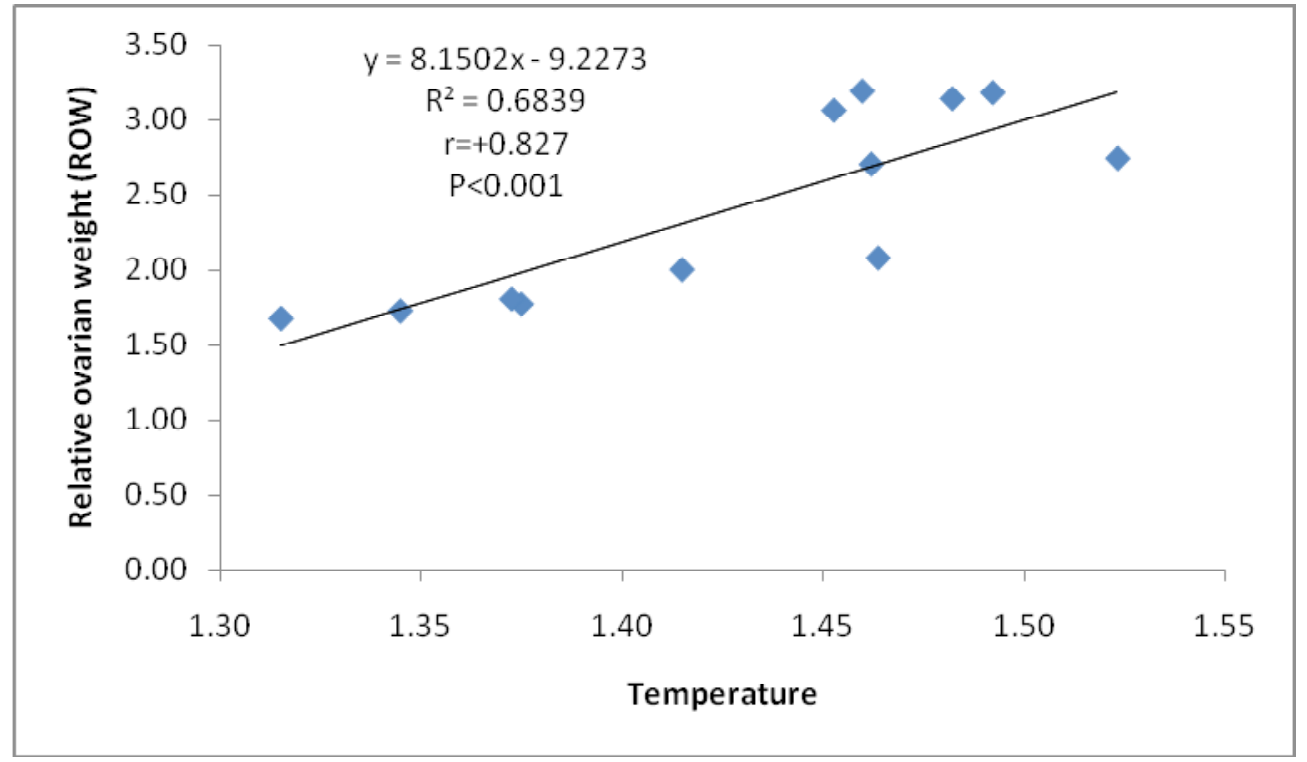

Fig.1A. Coefficient of correlation and regression analyses between temperature and relative ovarian weight (ROW) of female P. blanfordanus.

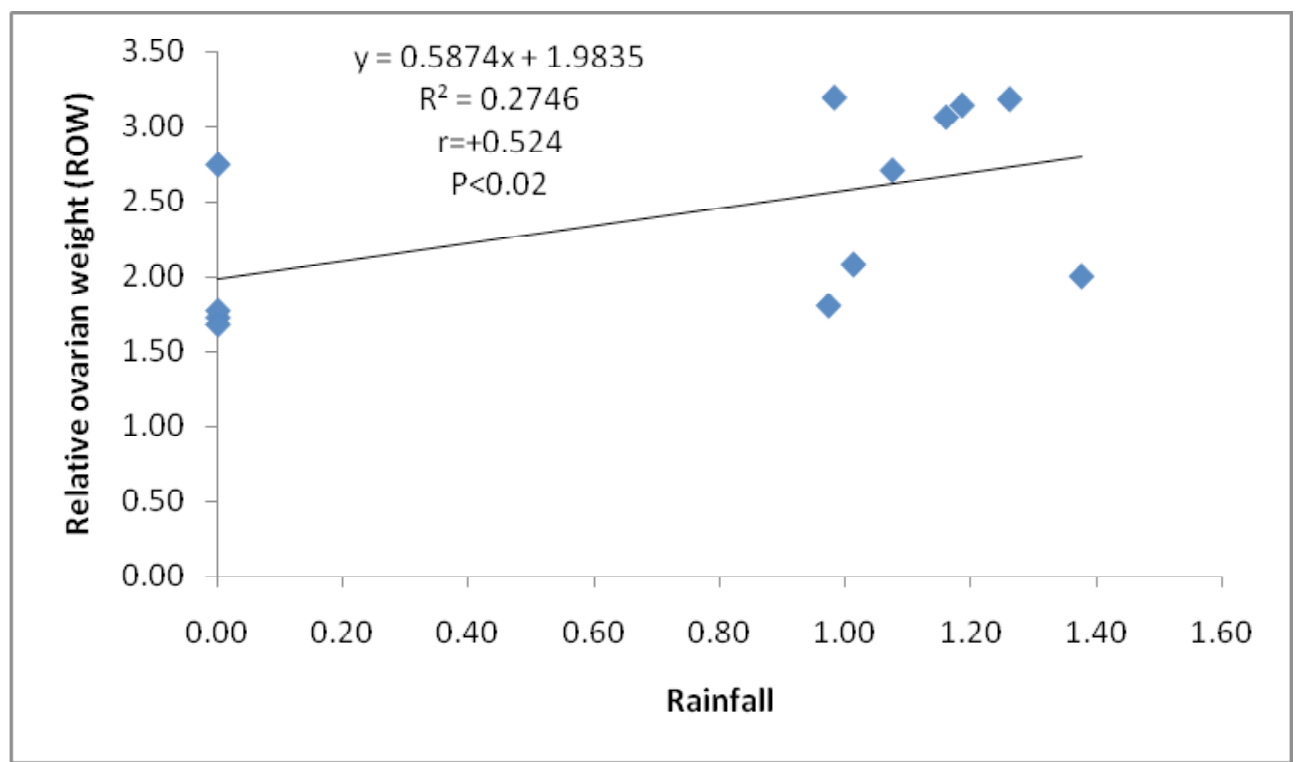

Fig.1B. Coefficient of correlation and regression analyses between rainfall and relative ovarian weight (ROW) of female P. blanfordanus. 


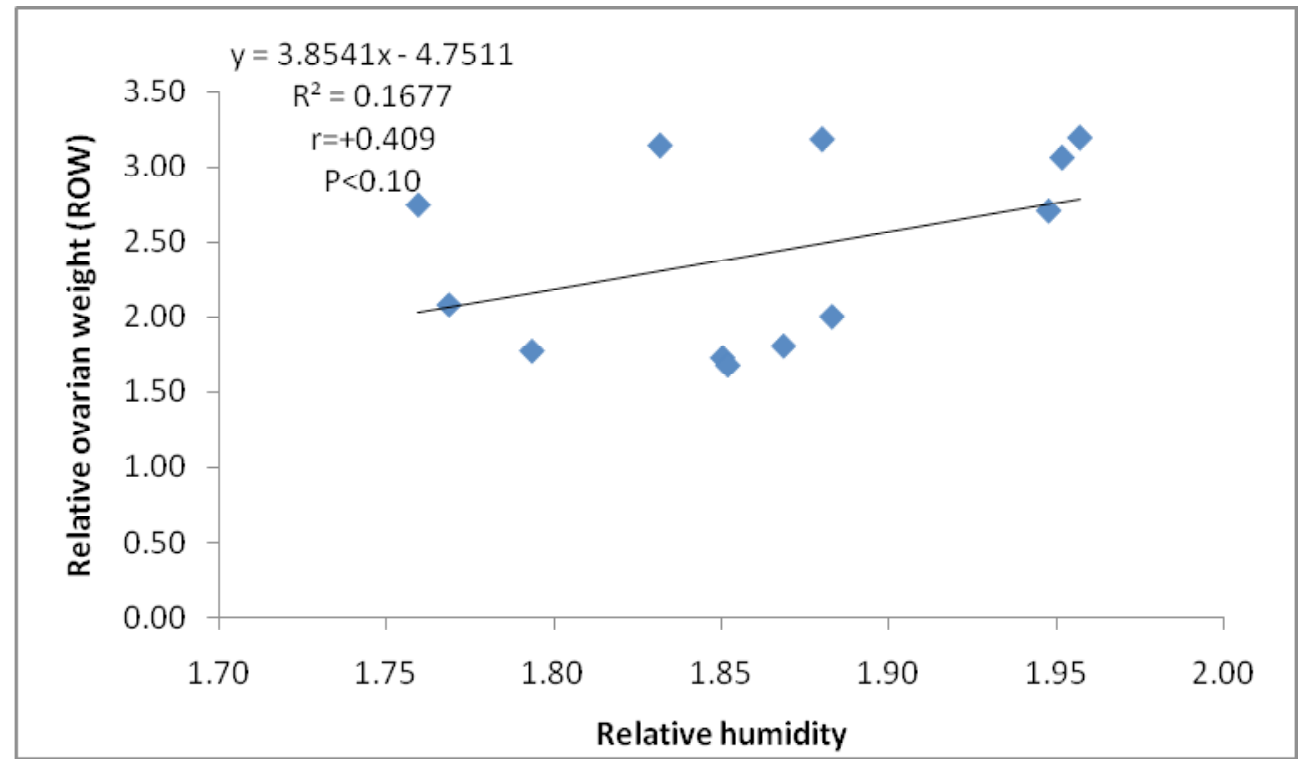

Fig.1C. Coefficient of correlation and regression analyses between relative humidity and relative ovarian weight (ROW) of female P. blanfordanus.

October - January/ February) of ovarian tissues. Therefore, the phase of reproduction (breeding) extends from April to August, vitellogenesis occurs between April to July, ovulation in April and May. Mating either precedes or occurs simultaneously with ovulation and fertilised eggs are retained upto 35 to 45 days in the oviduct. Females with oviductal eggs are encountered in the population from May to October though their number was relatively more during June to August. In Agama agama vitellogenic activities also show seasonal variation $^{42}$.

Both the ovarian and testicular activities are parallel with each other and so, there is synchrony between reproductive cycles of male and female in this animal. Therefore, the reproductive cycle of this animal is categorised as associated type $\mathrm{e}^{43}$. And the female is oviparous. It has been reported that a female lizard is receptive to a courting male when the ovary contains large preovulatory follicles, the size ranging from $6.0 \mathrm{~mm}$ or greater ${ }^{44}$. Our study shows that when largest follicles with yolk (ranges from $7.0 \mathrm{~mm}$ to $9.0 \mathrm{~mm}$ ) are there, the female is receptive and courtship with male takes place during this period ( late March to August), i.e., it is a summer breeder.

Ovarian weight could be an indicator of the female reproductive cycles ${ }^{45,}{ }^{46}$. $C$. versicolor $^{47}$, Varanus monitor ${ }^{26}$, P.dorsalis ${ }^{43}$, 49 of Indian species of lizards are also summer breeders. In oviparous lizards, like C. versicolor females show increased number of oviductal eggs during the month of July to October, and it is their breeding 


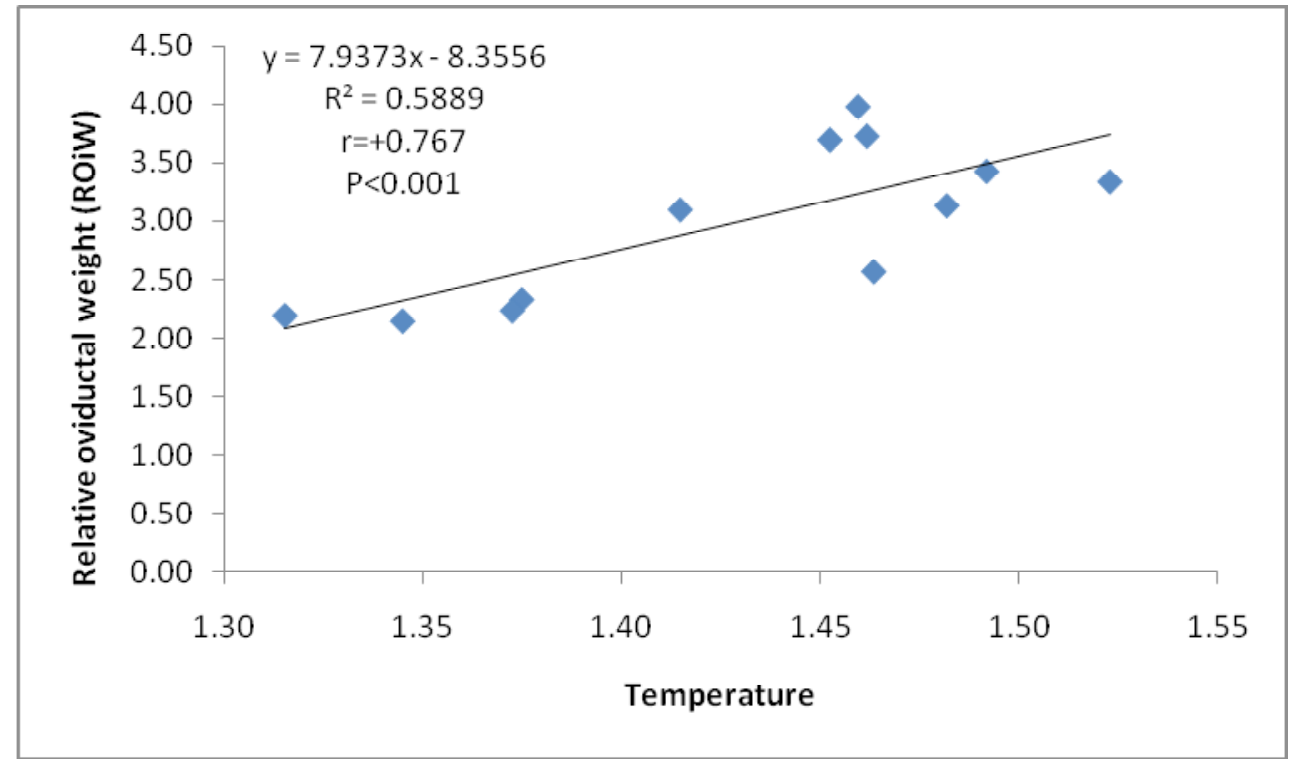

Fig.2A. Coefficient of correlation and regression analyses between temperature and relative oviductal weight (ROiW) of female P. blanfordanus.

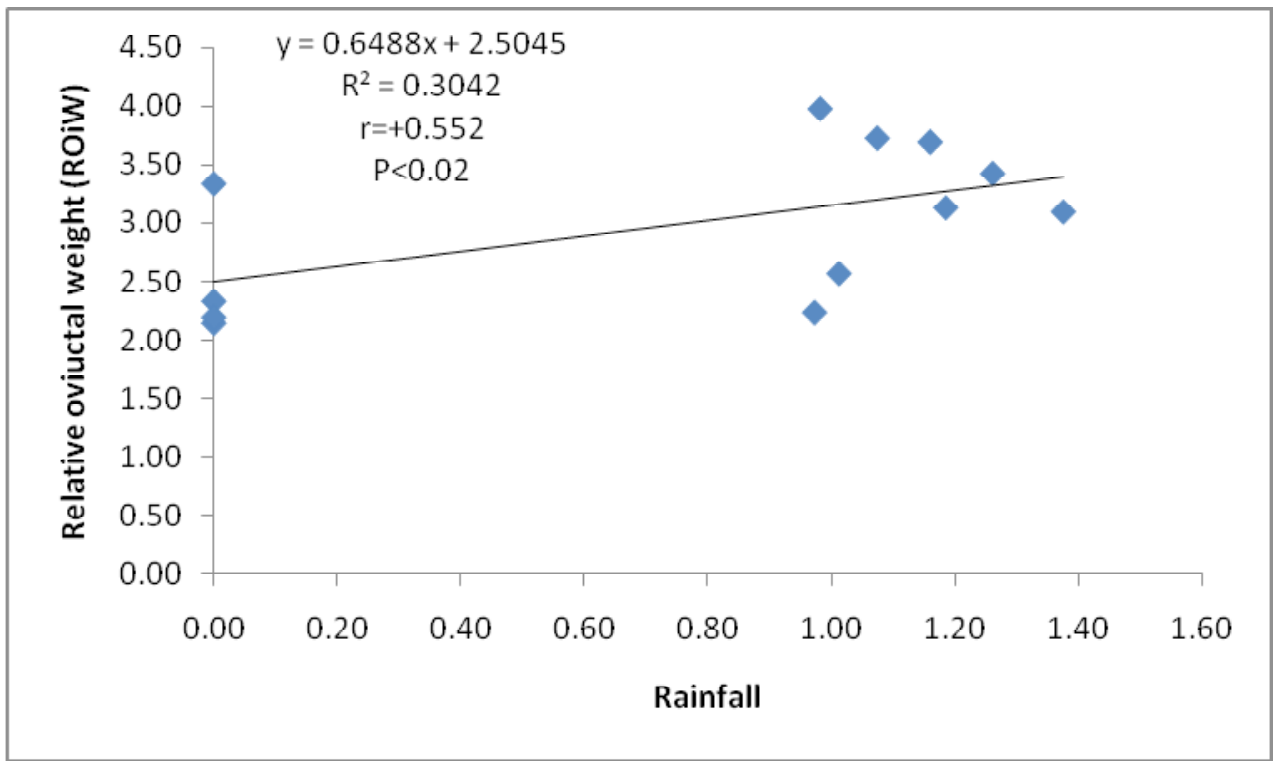

Fig.2B. Coefficient of correlation and regression analyses between rainfall and relative oviductal weight (ROiW) of female P. blanfordanus.

12 • J. Adv. Zool. 2019: 40(1) 


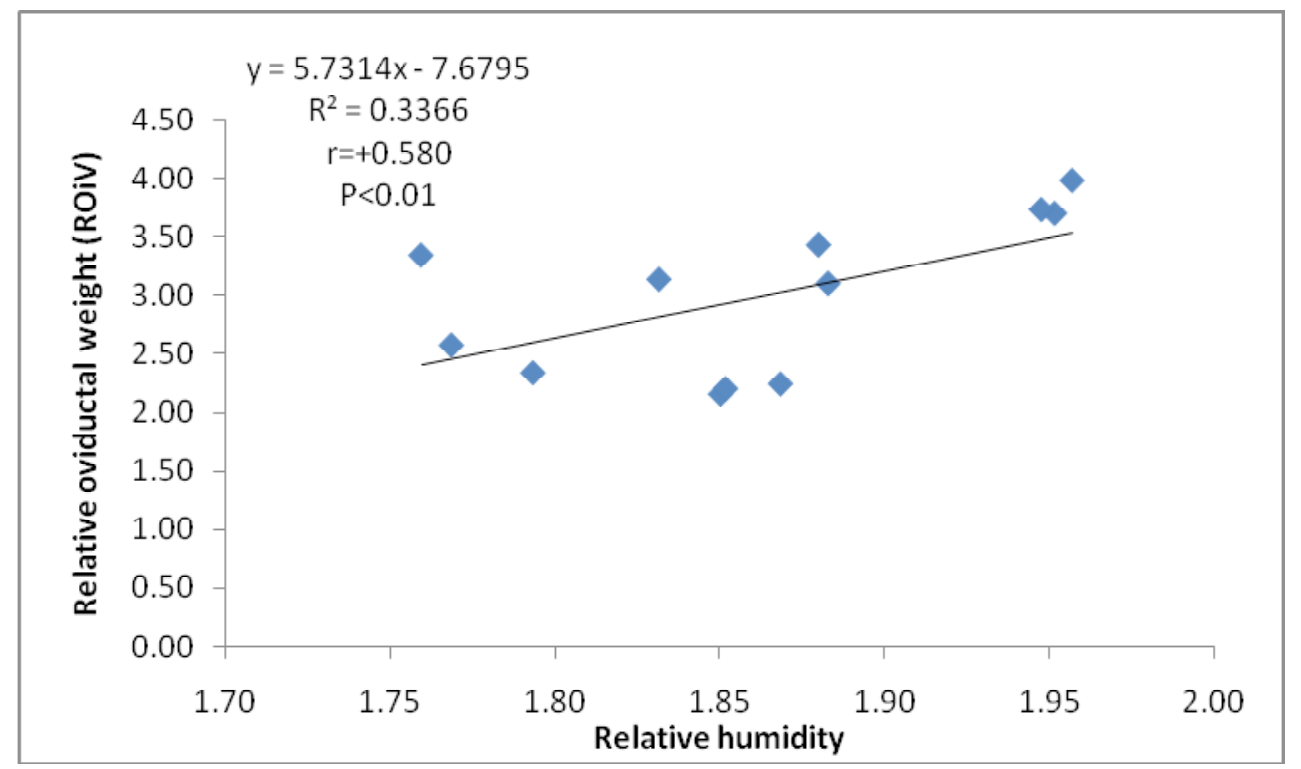

Fig.2C. Coefficient of correlation and regression analyses between relative humidity and relative oviductal weight (ROiW) of female P. blanfordanus.

season $^{47}$. Moreover, the annual reproductive cycle of $P$. dorsalis runs almost parallel to that of $C$. versicolor ${ }^{50}$. The peak reproductive phase of $V$. monitor occurs between April and June ${ }^{26}$. But in Barisia monticola, males are spermatogenetically active throughout the year without any effect of season on it whereas, the females are biannual ${ }^{51}$.

Each ovary in $P$. blanfordanus produces two to eight eggs per clutch and both the ovaries ovulate simultaneously. This may be categorised as polyautochronic type of ovulation as reported for other lizards $^{52}$. During the early half of the reproductive phase (March and April) both mature yolky follicles in the ovary as well as oviductal eggs are found simultaneously in the same lizard suggesting that this lizard belongs to multiple clutch type. Multiple clutches are also observed in the case of female Agama agama agama ${ }^{42}$. The study on the female $P$. blanfordanus revealed that the female reached sexual maturity at 9.5 $\mathrm{cm}$ of SVL as reported by Pradhan ${ }^{33}$.

Seasonal reproductive activity of reptiles is not only reflected in the cyclical changes that occur in the ovarian morphology and rate of oogenic activity but also in the structure and physiology of the oviduct. In all the reptilian species studied so far, oviduct weight increased in the prebreeding months, reached a peak prior to breeding and declined with the onset of oviposition, in post-breeding months they remained in a regressed state. In the present study the oviduct weight also increased during the preparatory phase (February to 
June) and remained high between April and September (breeding months) and then declined.

The observed size of the atretic follicles of $0.2 \mathrm{~mm}$ to $0.8 \mathrm{~mm}$ in the present study indicates that the atresia can affect follicles of different sizes. This is in good agreement with that of Guraya ${ }^{36}$, Wang etal. ${ }^{37}$ and Van $\mathrm{Wyk}^{53}$. Atretic mature vitellogenic follicles that have failed to ovulate as seen in this animal are also seen in other reptiles ${ }^{25,54,55,56}$. It is believed that during atresia phagocytic follicular cells invade the ooplasm and digest the yolk granules incompletely ${ }^{57,58,59}$. The phagocytic granulosa cells are also observed in this animal.

Absence of atretic follicles from June to August and very less in April/ May in this animal suggests that the number of preovulatory follicles matures as per the number of eggs to be ovulated. On the other hand, it is more from October to February (non-breeding season). Histochemical studies on the atretic follicles have showed that the atretic follicles are not merely degenerating elements of the ovary but they might synthesise biologically active steroid hormones for a short period $57,60,61$ and control the clutch $\operatorname{size}^{57,61}$. It is reported that in the case of turtle (Pelodiscus sinensis) that the yolk granules are eliminated in two ways: liquefaction and non-liquefaction processes ${ }^{37,62}$. In the case of $P$. sinensis shrinkage of oocyte membrane, bending of zona pellucida, granulosa cell proliferation and more vascular supply around atretic follicles are also observed ${ }^{58,59}$.

Relatively less height of granulosa cell during March to September (proliferative phase including reproductive phase) than in the month of October to February (nonreproductive phase) may be attributed to the migration of granulosa cell nuclei into the ooplasm of developing follicles, thereby causing decrease in its height. This is also supported by the findings that oocyte diameter is also 4 times larger in proliferative phase than the nonreproductive phase of this animal (Table 4). It has been reported in many lizards and snakes that the follicular cell nuclei migrate into the ooplasm of the developing follicles which might be a source of ooplasmic DNA reserve $^{47,63,64}$. However, these authors have opined that the significance of these nuclear migrations is yet to be clearly understood.

There are two types of corpus luteum occur red in the ovaries of vertebrates. One is formed by atresia of mature or maturing follicles and is known as the corpus luteum by atreisa. This is also called "preovulatory corpus luteum". The other types are derived from the empty follicles after ovulation or after the release of egg from the follicles called as corpus luteum of ovulation, which has also been variously designated as "ruptured follicles" or "discharged follicles" or "post-ovulatory follicles" or "corpus luteum" ${ }^{64}$. The corpus luteum of the oviparous lizards shows three stages of luteal development: 1) luteogenesis, 2) luteal maturity, and 3) luteal regression ${ }^{64}$. Further, 
equal number of oviductal eggs and corpora lutea in the ovary of one side suggests that the trans-ovarian migration is not in practice in this animal. Such trans-ovarian migration is generally seen in C.versicolor ${ }^{47}$.

The oogonia and oocyte are restricted to one or more discrete regions in the ovary known as germinal beds ${ }^{65,66,67,68}$. These vary greatly among the lizards and the number of germinal beds varies from single to six ${ }^{65}$, $67,68,69$. The structural organisation of the germinal bed also varies in different species of reptiles. In P.blanfordanus the germinal bed which is confined to the dorsal surface of the ovary as a single longitudinal band is similar as reported in the majority of reptiles ${ }^{25,65,70}$. The presence of two germinal beds has been reported in lizards one on each side of the ovary: C.versicolor ${ }^{69,71}$, Sitana ponticeriana ${ }^{21}$ and Leiolopisma metallicum $^{69}$. It is believed that the number of germinal beds might have a role in controlling the clutch size in reptiles ${ }^{69}$. More the germinal beds more the fecundity. Although $P$. blanfordanus has single germinal bed but probably have two clutches of eggs in its breeding season as is indicated by the presence of a batch of mature yolky follicles in the oviduct and a second batch in the ovary is similar to $P$. dorsalis and $M$. carinata who are polyautochronic lizards and have single germinal bed ${ }^{21}$.

The reptilian oviduct is a complex organ with a variety of functions (albumen production, egg shell production, placentation, oviposition or parturition, and sperm storage) depending on the parity mode of the species. These functions remain under complex physiological control ${ }^{72}$. The reduced thickness of oviductal muscle layers from April to August in the present study is meant to provide space for developing eggs which is supported by the fact that there is simultaneous increase in the ROiW and thickness of oviduct glandular layer.

\section{CONCLUSION}

From the strength of the correlation it can be safely concluded that so far as the magnitude of impact of environmental factors on reproduction of this animal is concerned, the temperature comes first, then rainfall and humidity. For the female of this tropical lizard, the reproductive phase is from February/March to August/September which includes both the recrudescence (regeneration) (pre-breeding) and reproductive (breeding) phases. The postbreeding or period of quiescence (regression) is from August/September to January/February. The results further indicate that the animal is summer breeder. The reproductive cycle is associated type, and its breeding behaviour is influenced by the local climatic conditions.

\section{ACKNOWLEDGEMENTS}

Deepak Kumar Singh is thankful to the University Grants Commission, New Delhi for financial support under the RGNF Scheme and Head, Department of Zoology, North Orissa University for providing necessary laboratory facilities. 


\section{REFERENCES}

1. Lofts, B. 1968. Patterns of testicular activity, In: Barrington EJW, and Jorgensen CB. (eds.), Prespectives of Endocrinology, Academic Press, New York. pp. 239-304.

2. Sherbrooke, W. C. 1975. Reproductive cycle of tropical Teiid lizard, Neusticurus ecpleopus (Cope) in Peru. Biotropica, 7: 194 - 207.

3. Guillette, L.J., Jr., \& W.P. Sullivan, 1985. The reproductive and fat body cycles of the lizard, Sceloporus formosus. Journal of Herpetology, 19: 474-480.

4. Jenssen, T.A. \& S.C. Nunez, 1994. Male and female reproductive cycles of the Jamaican lizard, Anolis opalinus. Copeia, 1994: 767780 .

5. Van Sluys, M., S.B. Martelotte, M.C. Kiefer \& C.F.D. Rocha, 2010. Reproduction in neotropical Tropidurus lizards (Tropiduridae): Evaluating the effect of environmental factors on T. torquatus. Amphibia-Reptilia, 31: 117126.

6. Malpaux, B. 2006. Seasonal regulation of reproduction in mammals. In: Knobil and Neill's Physiology of Reproduction, Third edn. Vol.2. Neill JD, Challis JRG, de Kreser DM, Pfaff DW, Richards JS, Plant TM, and Wassarman PM. (eds.) Academic Press, New York. pp. 3235

7. Murphy, K., S. Hudson, \& G. Shea, 2006. Reproductive seasonality of three coldtemperature viviparous skinks from southeastern Australia Journal of Herpetology, 40: 454-464.

8. Radder, R.S., A.E. Quinn, A.Georges, S.D. Sarre \& R. Shine, 2008b. Genetic evidence for cooccurrence of chromosomal and thermal sexdeterming systems in a lizard. Biology Letters, 4: 176-178.

9. Guillette, L.JJr. \& G. Casas-Andrew, 1987. The reproductive biology of the high elevation Mexican lizard Barisia imbricata. Herpetologica, 43: 29-38.

10. Rubio-Rocha, L.C., B.C. Book \& V.P. Paez,
2011. Continious reproduction under a bimodal precipitation regime in a high elevation anole (Anolis mariarum) from Antioquia, Colombia. Caldasia, 33(1): 91104.

11. Licht, P. 1967. Environmental control of annual testicular cycles in the lizard, Anolis carolinensis. I. Interaction of light and temperature in the initiation of testicular recrudescence. Journal of Experimental Zoology, 165: 505-516.

12. Colli, G.R., A.K. Peres, Jr. \& M.G. Zatz, 1997. Foraging mode and reproductive seasonality in tropical lizards. Journal of Herpetology, 31: $490-499$.

13. Gomides, S.C., L.B. Ribeiro, V.M. Peters \& B.M. Sousa, 2013. Feeding and reproduction ecology of the lizard Tropidurus torquatus (Squamata: Tropiduridae) in a rock outcrop area in southeastern Brazil. Revista Chilena de Historina Natural, 86: 137-151.

14. Fitch, H.S. 1970. Reproductive cycles in lizards and snakes. University of Kansas Musium of Natural History Publication, Kansas, 52: 1247.

15. Subba Rao, M.V. \& B.S. Rajabai, 1972. Reproduction in the ground lizard, Sitana ponticeriana and garden lizard, Calotes nemericola. British Journal of Herpetology, 4: $245-251$

16. Varma, S.K. 1970. Morphology of ovarian changes in the garden lizards, Calotes versicolor. Journal of Morphology, 131: 195209.

17. Varma, S.K. \& S.S. Guraya, 1975. Gross morphology of ovarian changes during the reproductive cycle of Indian lizards (Calotes versicolor and Hemidactylus flaviviridis). Acta Morphologica Neerlando-Scandinavica, 13: 201-212.

18. Kumari T.R.S., H.B.D. Sarkar \& T. Shivanandappa, 1990. Histology and histochemistry of the oviductal sperm storage pockets of the agamid lizard, Calotes versicolor. Journal of Morphology, 203: 97- 
106

19. Shanbhag, B.A. 2003. Reproductive strategies in the lizard. Calotes versicolor," Current Science, 84: 646-652.

20. Pandav, B.N., B.A. Shanbhag \& S.K. Saidapur, 2010. Growth patterns and reproductive strategies in the lizard, Calotes versicolor raised in captivity. Acta Herpetologica, 5: 131-142.

21. Sarkar, H.B.D. Shivanandappa, T. 1989. Reproductive cycles of reptiles. In: S.K. Saidapur (eds.), Reproductive Cycles of Indian Vertebrates. Allied Publishers, New Delhi. pp. $224-271$.

22. Radder, R.S. \& B.A. Shanbhag, 2003. Interrelationships among reproductive traits of the female lizard, Sitana ponticeriana. Current Science, 85: 89-91.

23. Sanyal, M.K. \& M.R.N. Prasad, 1966. Sexual segment of the kidney of the Indian house lizard, Hemidactylus flaviviridis Rüppell. Journal of Morphology, 118: 511-527.

24. Sanyal, M.K. \& M.R.N. Prasad, 1967. Reproductive cycles of the Indian wall lizard, Hemidactylus flaviviridis Ruppell. Copeia, 1967: 627-633.

25. Guraya, S.S. \& S.K. Varma, 1976. Morphology of ovarian changes during the reproductive cycles of the house lizard, Hemidactylus flaviviridis. Acta Morphologica NeerlandoScandinavica, 14: 165-192.

26. Jacob, D. \& L.S. Ramaswami, 1976. The female reproductive cycle of the Indian monitor lizard, Varanus monitor. Copeia, 1976: 256260.

27. Dutta, S.K., M.V. Nair., P.P. Mohapatra \& A.K. Mahapatra, 2009. Amphibians and Reptiles of Similipal Biosphere Reserve. Regional Plant Resource Centre, Bhubaneswar, India.

28. Smith, M.A. 1935. Fauna of British India, Including Ceylon and Burma. Reptilia and Amphibia Sauria, Vol. II. Taylor and Francis, London. pp. 469.

29. Srinivas, S.R., S.N. Hegde, H.B.D. Sarkar \& T.
Shivanandappa, 1995. Sperm stograge in the oviduct of the tropical rock lizard, Psammophilus dorsalis. Journal of Morphology, 224: 293-301.

30. Radder, R.S., S.K. Saidapur \& B.A. Shanbhag, 2005. Population density, microhabitat use and activity pattern of the Indian rock lizard, Psammophilus dorsalis. Current Science, 89: 560-565.

31. Radder, R.S., S.K. Saidapur \& B.A. Shanbhag, 2006a. Big boys on the top: Effect of body size, sex and reproductive state on perching behaviour in the tropical rock dragon, Psammophilus dorsalis. Animal Biology, 56: 311-321.

32. Radder, R.S., S.K. Saidapur, R. Shine \& B.A. Shanbhag, 2006b. Language of lizards: Interpreting visual displays in the Indian rock lizard, Psammophilus dorsalis. Journal of Ethology, 24: 275-283.

33. Pradhan, B. 2000. Studies on Biology of Some Lizards of Orissa. Ph.D. Thesis, Utkal University, Bhubaneswar, India.

34. Tikader, B.K. \& Sharma, R.C. 1992. Handbook: Indian Lizards. Zoological Survey of India, Calcutta.pp. 250.

35. Stoliczka, F. 1871. Notes on new or little known Indian lizards. Proceedings of Asiatic Society, Bengal, 1871:192-195.

36. Guraya, S.S. 1973. Follicular atresia Proceedings of Indian National Science Academy, 39B: 311-322.

37. Wang, W., J. Li, J. Yu, Z. Jiang, Y. Si, S. Yin \& G. Qian, 2013. Morphologic analysis of atretic follicles in the Chinese soft-shelled turtle, Pelodiscus sinensis. Tissue and Cell, 45: 383-386.

38. Dytham, C. 2011. Choosing and Using Statistics: A Biologist's Guide, Third edn., WileyBlackwell Publication. Sussex, United Kingdom.

39. Guillette, L.J., Jr. \& D.A. Bearce, 1986. The reproductive and fat body cycles of the lizard, Sceloporus grammicus disparalis. Transactions of Kansas Academy of Science, 
89: 31-39.

40. Tinkle, D.W., H.M. Wilbur \& S.G. Tilley, 1970. Evolutionary strategies in lizard reproduction. Evolution, 24: 55-74.

41. Bona-Gallo, A. \& P. Licht, 1983. Effect of temperature on sexual receptivity and ovarian recrudescence in the garter snake Thamnophis sirtalis parietalis. Herpetologica, 39: 173182.

42. Ejere, V.C. \& J.A. Adegoke, 2005. Seasonal testicular histology and reproductive cycle of the rainbow lizard, Agama agama agama, L, (Agamide, Reptila) in Ile-Ife, South Western Nigeria. Animal Research International, 2(3): 393-398.

43. Singh, D.K., N. Mohanty \& N. Jena, 2016. Reproductive cycle of male common Indian lizard, psammophilus blanfordanus: Seasonal testis, epididymis and renal sex segment histology. The Journal of Zoology Studies, 3(6): 45-55.

44. Whittier, J.M. \& Tokarz R.R. 1992. Physiological regulation of sexual behavior in female reptiles. in: C. Gans and D. Crews (eds.), Biology of the Reptilia, Vol. 18, University of Chicago Press, Chicago, pp. 24-69.

45. Marshall, A.J. \& R. Hook, 1960. The breeding biology of equatorial vertebrates : Reproduction of the lizard Agama agama lionotus Boulenger at Lat. $0^{0} 01^{1} \mathrm{~N}$. Proceedings of Zoological Society, London, 134: 197-205.

46. Marion, K.R. \& O.J. Sexton, 1971. The reproductive cycle of the lizard Sceloporus malachiticus in Costa Rica. Copeia, 1971: 517-526.

47. Thippareddy, S. 1979. Studies on the Biology of Reproduction in the Garden Lizard, Calotes versicolor (Daud.). Ph.D. Thesis, University of Mysore, Mysore, India.

48. Shivakumar, G.R. 1980. Studies on the Reproductive Physiology of the Lizard, Psammophilus dorsalis (Gray). Ph.D. Thesis, University of Mysore, Mysore, India.

49. Radder, R.S., B.A. Shanbhag \& S.K. Saidapur,
2004. Yolk partitioning in embryos of the lizard, Calotes versicolor: Maximize body size or save energy for later use? Journal of Experimental Zoology, Part A. Comparative Experimental Biology, 301: 783-785.

50. Shanmukhamm, H.H. 1989. An Analysis of Some Biochemical Factors Involved in the Physiology of Reproduction in the Lizard, Psammophilus dorsalis. Ph.D. Thesis, University of Mysore, Mysore, India.

51. Vial, V.L. \& J.R. Stewart, 1985. The reproductive cycles of Barisia monticola, a unique variation among viviparous lizards. Herpetologica, 41: 51-57.

52. Smith, H.M., G. Sinelnik, J.V. Fawcett \& R.E. Jones, 1973. A survey of the chronology of ovulation in anoline lizard genera. Transitions of Kansas Academy of Science, 75: 107120.

53. Van Wyk, J.H. 1984. Ovarian morphological changes during the annual breading cycle of the rock lizard Agama atra (Sauria: Agamidae). Navorsinge van die Nasionale Museum, Bloemfontein, 4:237-275.

54. Varma, S.K. \& S.S. Guraya, 1973. Histochemical observations on the follicular atresia in the garden lizard ovary. Acta Morphologica Neerlando-Scandinavica, 11: 241-252.

55. Jones, R.E., R.R. Tokarz \& La F.T. Greek, 1975. Endocrine control of clutch size in reptiles. V. FSH-induced follicular formation and growth in immature ovaries of Anolis carolinensis. General and Comparative Endocrinology, 26 : 354-367.

56. Guraya, S.S. \& S.K. Varma, 1978. Histochemistry of ovarian changes in the house lizard, Hemidactylus flaviviridis. Acta Morphologica Neerlando-Scandinavica, 16: 199-223.

57. Saidapur, S.K. 1978. Follicular atresia in the ovaries of nonmammalian vertebrates. International Review of Cytology, 54: 225244.

58. Hei, N.N., H.L. Liu, H.J. Bao, X.Q. Han \& Q.S. Chen, 2010a. Histomorphological 
characteristics of oogenesis and vitellogenesis in Pelodiscus sinensis. Acta Hydrobiologica Sinica, 34: 656-662.

59. Hei, N.N., P. Yang, Y. Yang, J.X. Liu, H.J. Bao, H.L. Liu, H. Zhang \& Q.S. Chen, 2010b. Fine structural observation on the oogenesis and vitellogenesis of the Chinese soft-shelled turtle (Pelodiscus sinensis). Zygote, 2: 109120.

60. Guraya, S.S. 1976. Recent advances in the morphology, histochemistry and biochemistry of steroid-synthesizing cellular sites in the nonmammalian vertebrate ovary. International Review of Cytology, 4: 365409.

61. Mendez-De, L.C., L.J. Guillette \& C.M. Villagran-Santa, 1993. Differential atresia of ovarian follicles and its effect on the clutch size of two populations of the viviparous lizard Sceloporus mucronatus. Ecology, 7: 535-540.

62. Liu, Y., C.W. Liu \& Q.S. Chen, 1984. Studies on the gonadal development of a Chinese turtle (Trionyx sinensis). Acta Hydrobiologica Sinica, 8: 145-151.

63. Guraya, S.S. 1969. Follicle cell nuclei as the possible source for the formation of ooplasmic reserve DNA in the garden lizard: A Morphological and histolochemical study. Acta Embryolgiae Experimentalis (Palermo) 1969: 91-96.

64. Guraya, S.S. 1989. Ovarian Follicles in Reptiles and Birds, In: Burggren W, Ishii S, H. Langer H, Neuweiler G, Randall DJ (eds.), Zoophysiology, Vol.24. Springer-Verlag, Berlin. 1-285.

65. Shanbhag, B.A. 2002. Reproductive biology of
Indian reptiles. Proceedings Indian National Science Academy, B 68: 497-528.

66. Gomez, D. \& M.P. Ramírez Pinilla, 2004. Ovarian histology of the placentotrophic Mabuya mabouya (Squamata, Scincidae). Journal of Morphology, 259: 90-105.

67. Radder, R.S. \& R. Shine, 2007. Germinal bed condition in a polyautochronic singleclutched lizard, Bassiana duperreyi (Scincidae). Amphibia - Reptilia, 28, 159162.

68. Radder, R.S., L. Pizzatto \& R. Shine, 2008a. Morphological correlates of life history variation: Is lizard clutch size related to the number of germinal beds in the ovary? Biological Journal of Linnean Society, 94: 81-88.

69. Jones, R.E., T. Swain, J.L. Guillettee, Jr. \& K.T. Fitzgerald, 1982. The comparative anatomy of lizard ovaries, with emphasis on the number of germinal beds, Journal of Herpetology, 16: 240-252.

70. Shanbhag, B.A., L. Subraya \& S.K. Saidapur, 1998. Pattern of recruitment, growth of developing follicles, and germinal bed activity in the tropical gecko, Hemidactylus brooki. Journal of Herpetology, 32: 566572.

71. Shanbhag, B.A. \& B.S.K. Prasad, 1993. Follicular dynamics and germinal bed activity during the annual ovarian cycle of the lizard, Calotes versicolor. Journal of Morphology, 216: 1-7.

72. Girling, J.E. 2002. The reptilian oviduct: A review of structure and function and directions for future research. Journal of Experimental Zoology, 293: 141-170. 